\title{
STEVEN SAMPSON
}

\section{„... HVOR ER MIT \\ FÆDRELAND DOG HYGGELIGT“}

OLE FELDB EK: (red.) Dansk Identitetshistorie, bd. 1-4 København: C.A. Reitzels Forlag 1991-1992. I alt 2154 sider, illustreret. 1400 kr. eller 395 kr. pr. bind. ISBN 87-7421-696-1 indbundet.

Artiklens titel, en linie fra et bidrag til den nationale sangkonkurrence i 1818 , indeholder flere spørgsmål, der kan stilles i forlængelse af studiet af, hvad det er at være dansk. Hvem ville bidrage med sådanne udtryksformer som sange? Hvornår skabtes ideen om et egentligt fædreland og hvem identificerede sig med det? Hvilken slags egenskaber identificerede man som specifikt danske? Disse spørgsmål om hvem, hvad, hvor, hvornår og til dels hvorfor, behandles af en gruppe på 12 forskere, ledet af professor Ole Feldbæk fra Institut For Samtidshistorie. De fire binds 2154 sider indeholder 20 forskellige artikler, som hver især kan læses selvstændigt.

Feldbæks team består af historikere, filologer, litterater, en musikhistoriker og en kunsthistoriker. Otte kommer fra Københavns Universitet, fire fra nærliggende institutioner som Kunstakademiet, Lærerhøjskolen og RUC. Der er ingen deltagere fra institutioner vest for Roskilde. Og ingen antropologer. Artiklerne er nyskrevne, med undtagelse af en redigeret afhandling fra 1963 og en forelæsning fra 1989.

De fire bind er historisk anlagt, sådan at bind 1, ,Fædreland og modersmål“, strækker sig fra 1536 til 1789, bind 2 ender med 1848, bind 3 går til 1940 og bind 4 fra 1940 til 1990. Disse årstal er skelsættende i dansk identitetsdannelse, hvad enten de henviser til tyskerfejden i 1789 , det 19 . århundredes romantiske nationalisme eller almuens danskhed ved århundredskiftet. Det sidste bind, ,1940-1990“, omhandler digte og sange under besættelsestiden samt EF-debatten i 1972. Årgang 1990 refererer til en artikel om det danske sprog. Meget er sket med danskhedsopfattelsen i de sidste 20 år. Det er mig en gåde, hvorfor den ikke blev bragt up to date, nu da Ole Feldbæk trods alt er professor i samtidshistorie. 


\section{De fire binds indhold - og historie}

I det første bind, med titlen „Fædreland og Modersmål 1536-1789“, får vi præsenteret ideen, at danskhedsfølelse hovedsagelig var en sag for adelen i dens tro på kongen og riget som sådan. Den voksende følelse af at være dansk var ikke så meget rettet mod tyskerne eller andre fremmede, men for danskhed. Opfattelsen af det særligt danske, i sprog, i karakter, i landskab, blev styrket af udlændinges karakteristikker af danskere og reaktion på dem. Nationalfølelsen udvikles i 1700-tallet, især med loven om indfødsret og i 1789 i forbindelse med tyskerfejden. Man kan konkludere, at uden tyskere ville der ikke have været nogen danskhed.

Bind 2, „Et yndigt land, 1789-1848“, beskæftiger sig yderligere med dansk-tyske forhold, med den danske nationalsangskonkurrence i 1818, med skolens rolle i dannelsen af borgernes og bøndernes børn til danskere samt litteraturens og litteraturfagets rolle i både udkrystalliseringen af danskeren og dyrkelsen af danskheden. Danskhedsfølelse var især udbredt blandt de dele af befolkningen, der havde skolepensum og dannelsesprogram, der skrev sange og kendte digterne. Danskheden forblev et borgerligt, bymæssigt overklassefænomen. Det er i dyrkelsen af ,vor litteratur“, at det danske imagined community skabes. Som eksempel på, hvordan etniciteten dannes på dansk jord, er dette bind det bedste af de fire: Feldbæk, Vibeke Winge og især Flemming Conrads artikler om nationalsangskonkurrencen og litteraturhistorieskrivning er spændende. Men desværre spændende som kilde og ikke som teoretisk inspiration.

Fra kongen, adelen og borgerskabet kommer danskhedsturen i bind 3 til „Folkets Danmark, 1848-1940“. Her i dette, det største bind, med de fleste og meste varierede artikler, finder vi et 180 siders kapitel om Grundtvigs vej til danskheden og om måden, hvorpå Grundtvig går fra at være nordisk kosmopolit til at være pæredansk og rettet mod bondestanden med det levende ord. Danskeren som den fredsommelige, venlige, fremadstræbende og foretagsomme landmand bliver kernefiguren. Flemming LundgreenNielsen stiller det interessante spørgsmål om Grundtvigs rødder i tysk nationalromantik: „Alt det, der i Tyskland fører fra Herder og Fichte til katastroferne under Wilhelm 2. og Hitler, bliver i Danmark til folkehøjskole, andelsbevægelse og parlamentarisk og folkelig kultur, bygget på samtale og kompromiser, ideelt set altid med respekt for mindretal.“ (p.173). Det er nok derfor, grundtvigianerne havde så svært ved at håndtere modernisering og nazisme, som det beskrives af Henrik Nissen i samme bind.

Bind 3 indeholder flere andre artikler om nationalromantikkens konsekvenser, fra Niels W. Gades musik til politisk udvikling og massemobilisering omkring Slesvig. For mig det mest spændende af samtlige bidrag en lille perle om økonomisk nationalisme i Danmark. Her virkede toldloven, eksportspørgsmålet, køb dansk-kampagner og logoer til eksportvirksomheder som udtryk for danskhed. At være dansk var oprindelig lig med at støtte eksportorienteret landbrug. Industrien forsøgte ved hjælp af statsstøtte at ændre landbrugets position. Ikke bare digte og sange, men også økonomien, har deres kulturelle udtryksformer. For antropologerne er det altid godt at se økonomer genkende dem.

Det fjerde bind,der indeholder tre artikler, er kaldt „Danmark og Europa, 1940-1990“ og består hovedsagelig af et kapitel på 390 sider om besættelsestidens digte og sange, herunder også de danske nazisters. Dernæst følger en kort analyse af indholdet af flere hundrede EF-valgplakater fra 1972. Ikke et ord om Maastricht 1992 (der var trods alt tid: 
bind 4 udkom først i november 1992). Endelig kommer der en sociolingvistisk anlyse af danskernes sprogbrug, om sprogstriden, om korrekt dansk og om danskerens holdninger til eget og andres sprog. Her er de nordiske sammenligninger interessante, da danskere er mere laissez faire end andre nordiske lande hvad angår autoriteters styring af sproget. Bind 4's sider vrimler med digte, sange, billeder og illustrationer. Men det siger ikke ret meget om Danmark og Europa mellem 1940 og 1990.

$\mathrm{Og}$ så, med en udførlig gennemgang af en spørgeskemaundersøgelse om, hvad danskerne synes om sproget dansk, sluttes Dansk Identitetshistorie. Det er en skuffende slutning. Hverken tidspres eller manglende viden kan retfærdiggøre den manglende syntese i bogen, den manglende overgang eller sammenhæng mellem kapitlerne, den manglende oversigt og manglende konklusion eller perspektiverende kapitel og det manglende emneregister (jeg ville gerne have slået ordet ,danskhed“ op, men der er kun et navneregister. Faktisk er danskhed først brugt i 1836 af H.C. Ørsted).

Dansk Identitetshistorie har sin egen historie. Og den er typisk dansk, i og med at den afspejler de bureaukratiske organers rolle i styringen af dansk forskning. En dag i sommeren 1988 blev Ole Feldbæk ringet op af Det Humanistiske Fakultet og bedt om at samle en gruppe forskere for at forske i dansk identitetshistorie. Initiativet var et led i Forskningsrådets støtte til dansk grundforskning, og da der ifølge Feldbæk ,,ingen forskning eksisterede om emnet“, blev det besluttet at lave noget. Forskningsgruppen blev samlet af flere folk fra Det Humanistiske Fakultet, lektorer og professorer fra universitetets historie- og sprogfag samt fra andre institutioner som Nationalmuseet, Det Kongelige Bibliotek, Danmarks Lærerhøjskole, RUC osv.

De fire flotte bind, fulde af digte, sange, billeder, karikaturer og andre udtryk for danskheden, er blevet godt modtaget af offentligheden. Det første oplag på 2000 sæt af de fire bind er næsten helt udsolgt. Og Dansk Identitetshistorie har affødt to efterkommere: en populær miniudgave kaldet $P a ̊$ sporet af den danske identitet, redigeret af Flemming Lundgreen-Nielsen (1992)., samt Danskernes Identitet, en samling af kilder til Dansk Identitetshistorie, redigeret af Thorkild Borup Jensen (1993). Danskerne kan ikke få danskhed nok, lader det til. De hungrer efter deres egen historie.

Diskussion af, hvad danskheden er, hvor den kommer fra og hvilken fremtid den har, er nu en industri i sig selv. Sammen med mange andre bøger om danskerne, skrevet af herboende fremmede, samt konferencer og artikler om dansk identitet, som f.eks. de nylig udkomne Dansk Identitet?, redigeret af Uffe Østergård (1993) og Henning Silberbrandts Den Danske Syge (1993), må vi i hvert fald konkludere, at det oprindelige tomrum i identitetsforskningen, som var årsag til Det Humanistiske Fakultets henvendelse til Ole Feldbæk, er ved at blive fyldt op. Spørgsmålet bliver: Fyldt op med hvad?

\section{Butterfly collecting eller grundforskning?}

Det umiddelbare svar vil være, at forskning om dansk identitet stadigvæk er på det stadium, Edmund Leach kaldte butterfly collecting. Forskergruppens medlemmer, alle højt kvalificerede i hver deres fag, har samlet, skrevet, og gennemskrevet deres enkelte bidrag. Men der foretages ingen samlende vurdering eller analyse, hverken teoretisk, 
metodisk eller kontekstuelt, af projektets overordnede mål. Forfatterne konstaterer på hver deres måde, at der findes danske identitetsudtryk i forskellige former i de perioder, de beskæftiger sig med, og disse beskrives. Og betragtet som sommerfuglesamling er Dansk Identitetshistorie fremragende læsning. Man lærer igen om det, man har glemt fra gymnasiet, og meget mere. Og man lærer, at der eksisterer utallige arter af „sommerfugle", for så vidt som dansk identitet udtrykkes i så vidt forskellige former som nationalsang, digt, billedkunst, stenhuggeri, grundtvigianske tekster, skønlitteratur, skolebøger, erklæringer fra konger, politikere, socialister og nazister, Grundtvigs tanker og Brandes' taler, valgplakater til EF-afstemningen og meget mere. Man lærer også, hvordan folk forsker i disse ting, at der overhovedet er forskere, der sidder og beskæftiger sig med f.eks. den danske nationalsangskonkurrence i 1818, og at de analyserer bidragene i deres form og indhold.

Det smarte svar på butterfly collecting i samfundsvidenskaberne har altid været ,so what". Men de store teoretikere udi etnicitet og nationalisme kunne aldrig være blevet store, hvis ikke der også var ,droner“, der gik ud og samlede data om alle disse mangfoldige kulturelle udtryksformer. Butterfly collecting kræver også disciplin, udholdenhed, præcision og fremstillingsevne. Og de fleste af forfatterne til Dansk Identitetshistorie besidder uden tvivl disse kvaliteter.

Disse kvaliteter er også yderst nødvendige for en ordentlig videnskab., men ikke tilstrækkelige. Feldbæk og kompagni leverer en samling på fire bind. Men det er bare det: en samling af studier og egentlig ikke nogen identitetshistorie. Det er grundig forskning, men ikke grundforskning. Fraværet af kritisk og teoretisk refleksion skinner igennem. Ingen er klar over, hvad de gør, eller hvorfor de gør netop det, de gør. I en samling på 2154 sider er det eneste bidrag, der beskæftiger sig med hovedtræk i nationalismeforskning som sådan, ja, det er et kapitel på i alt fem (5!) sider. De fleste artikler undgår at drage nogen komparative konklusioner, selv om sammenligning er oplagt. Metodisk refleksion mangler totalt. De enkelte bidrag refererer til andre bidrag, men diskuterer dem ikke. Dette er sædvanlig praksis i artikelsamlinger, som ofte baseres på en enkelt konference. Men forskergruppen til studiet af dansk identitetshistorie var ikke noget endagsforetagende. Den arbejdede i halvandet år, og de fleste af medlemmerne sad i samme bygning. Dette burde have givet tid til den nødvendige gensidige befrugtning og syntese, der adskiller normal videnskabelig forskning og formidling, hvor grundig den end kan være, fra egentlig nyskabende grundforskning.

Der var tid til at samle folk og skrive fire bind, men ikke tid til en ordentlig introduktion, en teoretisk fremstilling, en syntetiserende renskrivning. Men er tiden problemet?

At Dansk Identitetshistorie kun er på fire bind ser ud til at være tilfældigt. Hvis professor Feldbæk havde fundet flere forskere, ville flere bidrag være sivet ind. Sommerfuglesamlingen ville have været større og mere omfattende. Vi ville have lært flere ting. Men jo flere ting man lærer, hvor der ingen rød tråd er, jo mere tilbøjelig er man til at rejse sig og stille spørgsmålet: „So what?"

Det er ikke meningen, at vi bare skal feje det arbejde, de 12 forfattere har leveret, til side. $\mathrm{Vi}$, som er underlagt forskningsadministration, og det gælder også mig selv i øjeblikket, er under et evigt pres for at bevise, at staten får noget for pengene - helst $\mathrm{i}$ antallet af trykte sider. I denne henseende har forskningsrådet og fakultetet med Dansk 
Identitetshistorie uden tvivl fået noget for pengene.

Men hvad er det, man har fået, ud over en samling af empiriske bidrag af formidlende karakter? (Undtagelser er der, men de bekræfter bare reglen). Hvad er der dog i vejen med lidt teori? Teorier hjælper os med at holde trådene sammen. De forklarer både det uforklarlige og det indlysende. Og de hjælper os til at forestille os emner og temaer, som endnu ikke er dukket op. Jeg har i hvert fald haft meget svært ved at finde nogen teori overhovedet. Bidragene er underholdende, endog spændende, men ikke tankevækkende i videnskabelig forstand. Tomrummet ligger derfor ikke i identitetsforskningen, for her forsker man meget overalt i verden. Det ligger snarere i forskernes faglige isolation fra al den samfundsforskning, der foregår rundt omkring dem, i universitetets kroge og afkroge og selv ude i de mørke hjørner af KUAmager, for slet ikke at tale om andre egne af landet. Dansk Identitetshistorie er et københavnerprojekt. For provinsens reaktion kan der henvises til to bøger fra Århus, Center for Kulturstudier: Stereotyper i Europa (1990), redigeret af Gunhild Agger, Barbara Gentikow og Ulf Hedetoft, samt Uffe Østergårds Dansk Identitet? (1993) (som i øvrigt indeholder Ole Feldbæks opridsning af hele projektet).

Endelig kan man også spørge sig i internationaliseringstider, hvorfor disse fire bind foreligger på dansk (omend med det sædvanlige engelsksprogede abstract). Forskning, især grundforskning, skal gøres tilgængelig. Forskning i identitet skal, for at den kan vurderes, foreligge i et sprog, som også er tilgængeligt for andre end dansklæsende. Med alle disse forskningsinitiativer ville det være interessant at vide noget om, hvorvidt grundforskningsinitiativet også inkluderer oversættelsen af bogen og diffusion af de enkelte afhandlinger til dem, der ikke kan dansk. Hvis det ikke er tilfældet, må vi konkludere, at Dansk Identitetshistorie selv indgår i konstruktion og reproduktion af danskheden.

\section{Helstatspatriotisme og etnisk danskhed}

Uanset manglen på teori er der trods alt en rød tråd i projektet. Tråden drages frem af projektets gudfader, Ole Feldbæk, hvis arbejde (til dels sammen med Vibeke Winge) omkring den tidlige identitetsdannelse, indfødsretten, tyskerfejden og skolesystemet dominerer første og andet bind. Lad os for god ordens skyld ridse Feldbæks ideer op, da de er både stimulerende og provokerende. Der var, siger Feldbæk, to slags danskhed. Den første var kærlighed til et fædreland bestående af kongens rige. Dette skal forstås adskilt fra danskheden i nutidig betydning: Identifikation med en bestemt kultur, som har fælles sprog, historie, karakter osv., dvs. en kultur, som ikke er f.eks. tysk, norsk eller tyrkisk.

Den tidlige brug af danskhed var derfor begrænset til magthavernes brug. Hvis der i feudale tider var tale om Danmark og danskerne, havde det at gøre med kongeriget. Den senere dyrkelse af danskheden, siger Feldbæk, var baseret på en helstatspatriotisme, hvor „Danmark“ bestod af danskere, nordmænd og tyskere. Uanset hvor man var født og hvilket sprog, man talte, kunne man være en god dansker, så længe man var tro mod kongen. Kongens embedsfolk var tyskere, og adelen var kosmopolitisk. Dansk Kultur 
(med stort K) foregik på tysk. Rigets bønder talte dansk, tysk eller norsk og forblev bønder af stand. Men deres forbindelse var til deres gård, egn eller købstad. En dansk etnisk følelse havde de ikke. Dansk, Danmark og danskhed sagde dem ikke noget.

Etnisk, dvs. kulturbaseret, danskhed vokser først frem, når det dansktalende borgerskab begynder at se de tysktalende embedsmænd samt den "fremmede" adel som hindring for deres egne karrierer. Danskhedsfølelsen bliver så et bevidst middel, hvorimod troen på Gud og kongen gradvis bliver erstattet af de borgerlige intellektuelles fædrelandstankegang og senere - gennem gårdmænd, grundtvigianere og arbejderbevægelsen - til en mere udbredt opfattelse af danskhed som tilhørende fædrelandet og folket.

Vi har derfor at gøre med flere slags danskhed, centreret omkring forskellige grupper på forskellige tidspunkter. Hovedsagelig en danskhed, der begynder i snævre kredse på toppen og siver ned, eller breder sig, til masserne. Danskheden er noget, man manipulerer med og som har grader af intensitet, siger Feldbæk.

Loven om indfødsret (1770) spiller en central rolle i denne konkurrence mellem det frustrerede borgerskab og de tyske embedsmænd. Tyve år senere markeres starten til en egentlig danskhedsfølelse gennem tyskerfejden og hævdelsen af alt dansk blandt borgerskabet, de gejstlige samt blandt handelsfolkene i købstæderne. Brugen af ordet „følelse“ er ikke malplaceret her. Som Feldbæk flere gang påpeger, er den voksende danskhedsidentifikation ikke bare en strategi, men en følelsesmæssig sikkerhedsventil for frustrationer blandt dem, der ikke kan få livet og eksistensen til at hænge sammen på andre måder. Feldbæk relaterer danskhedens opkomst til kirkens forfald som åndeligt svar. Religion bliver tæmmet og så erstattet af nationalfølelse, som giver samme tryghed, visioner og svar på livets spørgsmål. Nationalfølelse udfylder et følelsesmæssigt tomrum.

Men udover følelse skal der andet til at forklare danskhedens opståen. Danskheden udvikler sig relativt tidligt sammenlignet med nationale strømninger andre steder i Europa, der først blomstrer i midten af 1800-tallet. Materiel velstand og uddannelse giver flere grupper både lysten til og muligheden for at kigge ud over de lokale grænser og identificere sig med Danmark. Feldbæks arbejde, og Dansk Identitetshistorie i det hele taget, kan fungere som empirisk bevis på både Ernest Gellners og Benedict Andersons nationalismeteorier (cf. Gellner 1983, Anderson 1991).

Gellner bekræftes, i og med at sekularisering og industrialisering og statens institutioner som lovgiving og skole skaber danskheden. Danskheden vokser frem på grund af kampen for statsmagten, imod Enevælden osv. Det er denne institutionalisering, ledsaget af en fredelig bondestand, der var læsevant og lovlydig, der gjorde, at danskheden opstår tidligere end etniske identiteter andre steder i verden. Andersons Imagined Communities bekræftes i og med, at vi kan se, hvem det er, der først dyrker etnisk danskhed: ikke bønderne og folket, men snarere dem, der råber: „Folket“, dvs. de intellektuelle og de lavere embedsmænd, der oplever, at deres karriere blokeres. Disse mennesker bliver frustrerede, og i deres fremmedgjorthed bruger de kulturen - danskheden - som kampvåben. Fjenden er kongemagten og dens tjenere: tyskere samt de kosmopolitiske franko/germanofile aristokrater.

Endelig kan man opfatte Dansk Identitetshistorie som en bekræftelse af antropologiske teorier om identitetsdannelse: Bevidstheden dannes ikke indefra eller nedefra, men i 
kontakt med andre: lokale tyskere i tyskerfejden, udenlandske konkurrenter i f.eks. Det Danske Kunstakademi eller i gårdmænds konfrontation med de fremmedartede byboere og politikere.

Fjendebilleder, tyskerhad, ophøjelse af det danske, ja, disse fænomener spreder sig under begivenhederne i 1814, 1849, 1864 og 1920 længere ud til flere grupper. Fra det oplyste borgerskab til handelsfolk og gårdmænd og fra gårdmænd til grundtvigianske husmænd. Gårdmænd og husmænd transformerede danskheden fra at være det oplyste borgerskabs udtryksform til folkelighed. Endelig bliver det arbejderklassens tur til at tilegne sig en dansk identitet. I kølvandet på 1. verdenskrig og 2. Internationales fallit må den danske arbejderbevægelse nedtone sin internationalisme til fordel for en særlig dansk vej til velstand.

Danskheden er gået fra at være troen på konge og helstatspatriotisme til at være hele folkets eje, og danskeren hyldes i nationaldigte, i besættelsestidens sange, i folkekarakterbeskrivelser og i ritualer som landskampe eller EF-kampagner.

Danskheden som identitet har derfor forskellige grader af intensitet, siger Feldbæk. Den er der, men den er der ikke for alle grupper på samme tidspunkt. Danskheden tager til og tager af under bestemte konjunkturer: I 1820 vil folk hellere læse Walter Scott end dansk nationalitteratur. I dag er Højskolesangbogen blevet genoptrykt uden alle disse internationale sange og endda hyldet af intellektuelle for dens nordiske præg.

Dansk Identitetshistorie lægger op til, men beskæftiger sig desværre ikke med, hvad der sker i dagens danske identitetsdiskurs. Faktisk har danskheden ikke været oppe at vende hele tiden. I efterkrigstiden var danskheden uinteressant indtil 70'ernes diskussioner om EF og om fremmedarbejdere. Op igennem 70'erne var mange, især de fremtrædende intellektuelle og venstrefløjen, optaget af deres identiteter. Men denne identitetssøgning handlede enten om den personlige identitet (den indre rejse, med alt fra Freud over LSD til selvoptagethed) eller om solidaritet med folket i Danmark eller verden (jo fjernere, jo bedre). Denne identitetssøgning blev gjort ved hjælp af forskellige alfabetpartier og fraktioner.

I dag ser vi dette mærkelige sammenspil mellem kosmopolitisme og nationalfølelse: Den danske venstrefløj, nej-sigerne, dem, der tidligere opfattede sig selv som internationale og kosmopolitiske, som antiracistiske og positivt disponeret over for fremmede, disse mennesker er nu i samme båd som den xenofobiske Danske Forening. Disse ellers forskellige fløje taler begge om „truslen mod danskheden“. Forskellen er, om man opfatter truslen som kommende udefra (nej-folkenes frygt for Unionen) eller indefra (Den Danske Forenings frygt for ,papirdanskere“). Indfødsretten er i dag atter aktuel: Den Danske Forening klager over, at indvandrere får dansk indfødsret „uden krav om danskhed“. Mens den tidligere kosmopolitiske, „solidariske“ venstrefløj nu er blevet provinsiel og forsvarer for Danmark, er Venstre, CD og Konservative blevet kosmopolitiske: de er ,europæere“.

\section{Grundig og underholdende}

En forskergruppe, som oven i købet skulle drive grundforskning og som kunne beskæf- 
tige 12 akademikere over en periode på omkring to år og kunne udgive fire flotte bind, måtte kunne finde tid til lidt syntese. Men tiden er ikke problemet. Vi har altid tid, hvis vi har lyst. Hvorfor var der ingen lyst til at syntetisere, til at sige noget om hele molevitten, til at ,go out on a limb“ og provokere? Det gør Feldbæk selv, næsten parentetisk, når han taler om nationalismens erstatning af religion, men så bliver provokationen til „Further research is needed ..."

Kommer der så et bind 5? Bliver Dansk Identitetshistorie opdateret hvert år ligesom Encyclopedia Britannica, med en slags Identitetshistoriens Arbejdsmark? Eller skal man afvente et nyt opkald fra fakultetet med tilhørende bevilling og frikøb?

Man fristes til at tro, at store gruppeprojekter som dette, med deres generelle titler og manglende teoretiske endsige begrebsmæssige udgangspunkt, munder ud i videnskabens værste mareridt: der skrives mere og mere om mindre og mindre.

Man må konkludere, at grundig forskning ikkeer grundforskning. De enkelte artikler er alle sammen interessante. De gør os opmærksom på temaet: at danskheden udtrykkes overalt, forskelligt i forskellig sammenhæng. Læseren kan dermed bruge bogen som etnografisk kilde men ikke som begrebsmæssig inspiration. Så opfrisk din historieundervisning, litteraturkundskab, kunsthistorie og digtsamlinger. Køb de fire bind og hyg dig.

\section{Litteratur}

Agger, G., B. Gentikow \& Ulf Hedetoft (red.)

1990 Stereotyper i Europa. Århus: Aarhus Universitetsforlag

Anderson, Benedict

1991 [1983] Imagined Communities. London: Verso

Gellner, Ernest

1983 Nations and Nationalism. Oxford: Blackwell

Jensen, Thorkild Borup (red.)

1993 Danskernes Identitetshistorie: en antologi til belysning af danskernes selvforståelse.

København: C.A. Reitzel

Lundgreen-Nielsen, Flemming (red.)

1992 På sporet af den danske identitet. København: Spektrum

Silberbrandt, Henning

1993 Den Danske Syge. Højbjerg: Forlaget Hovedland

Østergård, Uffe (red.)

1993 Dansk Identitet? Århus: Aarhus Universitetsforlag 